\title{
Simulasi Pencahayaan Buatan untuk Ruang Kelas dengan Tipe Armature TL LED dan Bohlam LED
}

\author{
Arimaz Hangga ${ }^{1}$, Alim Muanifatin $\mathrm{Nisa}^{2}$, Dewangga Pratama ${ }^{3}$, dan Muchlisin Apriliyanto ${ }^{4}$ \\ Jurusan Teknik Elektro, Fakultas Teknik, Universitas Negeri Semarang \\ Gedung E8, Kampus UNNES Sekaran, Gunungpati, Semarang, 50299, Indonesia \\ arimaz.hangga@mail.unnes.ac.id ${ }^{1}$, alimnisa05@students.unnes.ac.id ${ }^{2}$,dwppradewa19@gmail.com ${ }^{3}$, \\ muchlisin0408@students.unnes.ac.id ${ }^{4}$
}

\begin{abstract}
Classroom light intensity is one of the essential factors in the learning process. Several factors affect light intensity in the classroom, i.e., determination of classroom design, position of objects in the classroom, window design, shading devices, type of lamp, and type of lamp armature. The research aims to determine the effect of armature lamp type. The results of this research are expected to increase the efficiency of electricity costs and use the classroom optimal lighting system according to Indonesian National Standard (SNI). Two types of lamp armature used in this research i.e. LED tube armature and LED bulb armature. This research used E11-210 classroom in E11 Building of Electrical Engineering Department, Universitas Negeri Semarang with the size of $12 \mathrm{~m} \times 9 \mathrm{~m} \times 3.5 \mathrm{~m}$. Simulation in this research used Dial ux Evo 9 software. The resul ts of observations and simulations show that E11-210 classroom had not followed SNI yet, in 350 lux. Based on simulation results, it shows that using LED tube armature and LED bulb armature will get light intensity of E11-210 classroom that follow SNI 6197:2011. Simulation results show that the use of LED tube armature (Powerbalance Gen2 RC463B) in E11-210 classroom will increase efficiency of electricity costs by $27.81 \%$. Meanwhile, the use of LED bulb armature (Luxspace Ace Acccent RS75OB) in E11-210 classroom will increase efficiency of el ectricity costs by $33.96 \%$.
\end{abstract}

Keywords - LED tube armature, LED bulb armature, efficiency of electricity costs, SNI

\begin{abstract}
Abstrak- Salah satu faktor penting yang mempengaruhi proses belajar mengajar di dalam kelas adalah intensitas cahaya. Terdapat beberapa faktor yang mempengaruhi intensitas cahaya dalam ruang kelas antara lain: penentuan desain ruang kelas, posisi benda-benda dalam ruang kelas, desain jendela, desain tirai, jenis lampu, dan jenis lamp armature. Penelitian ini bertujuan untuk mengetahui pengaruh dari jenis lamp armature. Sehingga hasil penelitian ini diharapkan dapat meningkatkan efisiensi biaya listrik dan menggunakan sistem pencahayaan yang optimal dalam ruang kelas sesuai dengan Standar Nasional Indonesia (SNI). Terdapat 2 macam tipe lamp armature yang digunakan dalam penelitian ini yaitu armature TL LED dan armature Bohlam LED. Penelitian ini menggunakan ruang kelas E11-210 Gedung E11 Ju rusan Teknik Elektro Universitas Negeri Semarang dengan ukuran $12 \mathrm{~m}$ x $9 \mathrm{~m} \times 3,5 \mathrm{~m}$. Simulasi dalam penelitian ini menggunakan perangkat lunak Dialux Evo 9. Hasil observasi dan simulasi menunjukkan bahwa ruang kelas E11-210 masih belum memenuhi SNI 6197:2011 yaitu 350 Lux. Berdasarkan hasil simulasi menunjukkan bahwa dengan adanya pergantian armature TL LED dan armature Bohlam LED yang tepat akan didapatkan intensitas cahaya ruang kelas E11-210 memenuhi standar SNI 6197:2011. Hasil simulasi menunjukkan bahwa penggunaan armature TL LED (Powerbalance Gen2 RC463B) pada ruang kelas E11-210 akan meningkatkan efisiensi biaya listrik sebesar 27,81 \%. Sedangkan dengan penggunaan armature Bohlam LED ruang kelas E11-210 (Luxspace Ace Accent RS750B) akan meningkatkan efisiensi biaya listrik sebesar $33,96 \%$.
\end{abstract}

Kata kunci-armature TL LED, armature Bohlam LED, efisiensi biaya listrik, SNI

\section{PENDAhUluAN}

Data statistik [1], [2] menunjukkan bahwa konsumsi energi listrik di Indonesia pada tahun 2017 sebesar 267,45 GWh dengan proyeksi rata-rata kebutuhan listik hingga 2027 sebesar $10,1 \%$. Bidang pencahayaan merupakan salah satu bidang yang sering digunakan dalam sektor pendidikan, rumah tangga, industri maupun komersil. Pada sektor pendidikan, bidang pencahayaan sangat mempengaruhi dala $\mathrm{m}$ proses belajar mengajar di dalam kelas.
Penelitian peningkatan efisiensi sistem pencahayaan dan penggunaan sistem pencahayaan secara optimal sangat berkembang pesat selama satu dekade terakhir. Beberapa metode peningkatan efisiensi dan penggunaan sistem pencahayaan secara optimal antara lain : pergantian jenis lampu [3] - [10], sistem pencahayaan yang diredupkan [11], [12], penambahan tirai dalam ruangan [13], [14], dan kombinasi pencahayaan cahaya alami dan buatan [15], [16]. Akan tetapi peningkatan efisiensi sistem pencahayaan dengan pergantian lamp armature masih belum diketahui secara 
signifikan. Penelitian ini bertujuan untuk mengetahui pengaruh dari jenis-jenis lamp armature dalam ruang kelas.

Penggunaan lamp armature dan jenis lampu dalam ruang kelas yang tepat akan memberikan kenyaman visual dalam proses belajar mengajar [17] sehing ga didapatkan peningkatan produktifitas [18]. Hal ini dikarenakan setiap lamp armature dan jenis lampu memiliki distribusi pencahayaan yang berbeda-beda [3], [5]. Oleh karena itu diharapkan dalam penelitian ini memberikan solusi yang tepat dalam pemilihan lamp armature sehingga didapatkan optimalisasi pencahayaan ruang kelas sesuaidengan SNI.

\section{METODE}

Ruang kelas yang digunakan dalam penelitian ini adalah ruang kelas E11-210 Gedung E11 Universitas Negeri Semarang dengan ukuran $12 \mathrm{~m}$ x $9 \mathrm{~m}$ x $3,5 \mathrm{~m}$ seperti pada Gambar 1 (a). Desain pemasangan 8 lamp armature yang digunakan saat ini pada ruang kelas E11-210 dapat dilihat pada Gambar 1 (b).

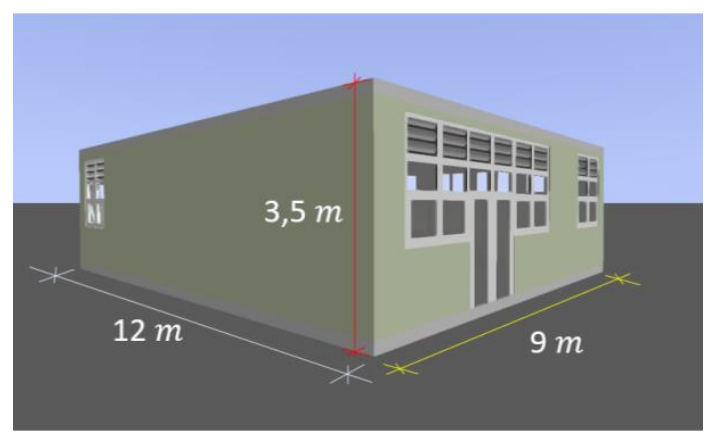

(a)

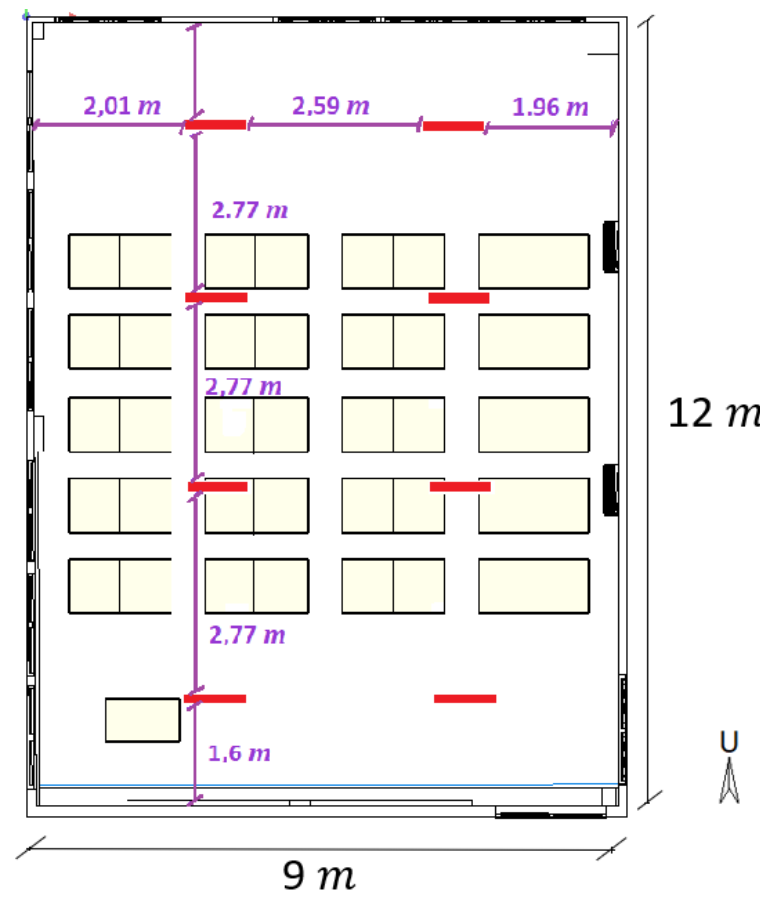

(b)

Gambar 1. Desain ruang kelas E11-210 (a) 3 dimensi dan (b) pemasangan lamp armature yang digunakan saat ini
Pengukuran intensitas pencahayaan ruang kelas E11-210 dilakukan dengan menggunakan metode pengukuran umum dan pengukuran setempat. Ruang kelas E11-210 memiliki luas ruangan $108 \mathrm{~m}^{2}$ sehingga pengukuran umu m ruang kelas E11210 me miliki jarak antar titik ukur sebesar 3 m sesuai dengan SNI 16-7062-2004 [19] seperti pada Gambar 2 (a). Sedangkan pengukuran setempat ruang kelas E11-210 dapat dilihat pada Gambar 2 (b).

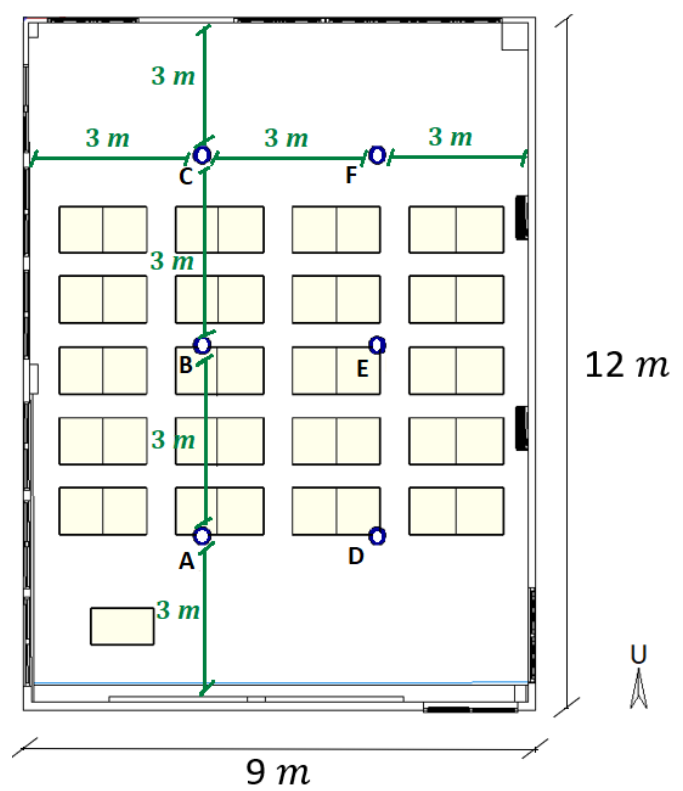

(a)

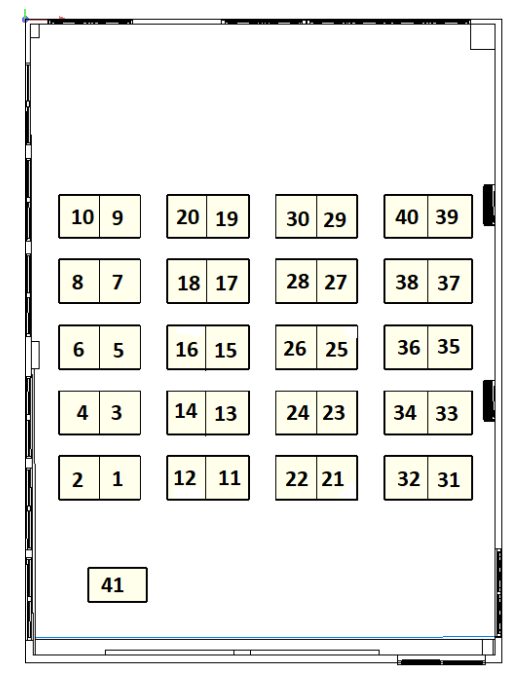

(b)

Gambar 2. Desain pengukuran (a) umum dan (b) setempat pada ruang kelas E11-210 dengan ukuran $12 \mathrm{~m} \times 9 \mathrm{~m} \times 3,5 \mathrm{~m}$

Pengukuran intensitas pencahayaan pada penelitian ini dilakukan secara observasi dan simulasi. Pengukuran intensitas cahaya secara observasi dan simulasi dilakukan dengan pengambilan data pada malam hari pukul 20.00 dan ruangan dikondisikan tidak ada cahaya luar yang masuk ke dalam ruang kelas. Sehingga pada pengukuran secara observasi dan simulasi hanya terdapat pencahayaan buatan yang di dalam ruang kelas. 
Pengukuran observasi dilakukan sebanyak 10 hari dengan pengambilan data masing-masing titik pengukuran dilakukan perulangan sebanyak 10 kali. Luxmeter Metrel Eurotest XE yang telah dikalibrasi oleh Ko mite Akreditasi Nasional (KAN) S1900496 digunakan untuk pengukuran intensitas ruang kelas secara observasi. Perangkat lunak yang digunakan dalam simulasi pada penelitian ini adalah Dialux Evo 9. Desain ruang kelas E11-210 didesain menggunakan Dialux Evo 9 seperti yang terlihat pada Gambar 3. Proses belajar mengajar pada ruang kelas E11-210 menggunakan 16 la mpu Philips TLD 36 watt 2500 lumen dengan 8 armature Artolite RM300 M2. Berdasarkan SNI 6197:2011 [20] maka penelitian ini menggunakan standar intensitas cahaya pada pengukuran setempat dalam ruang kelas sebesar 350 Lux.

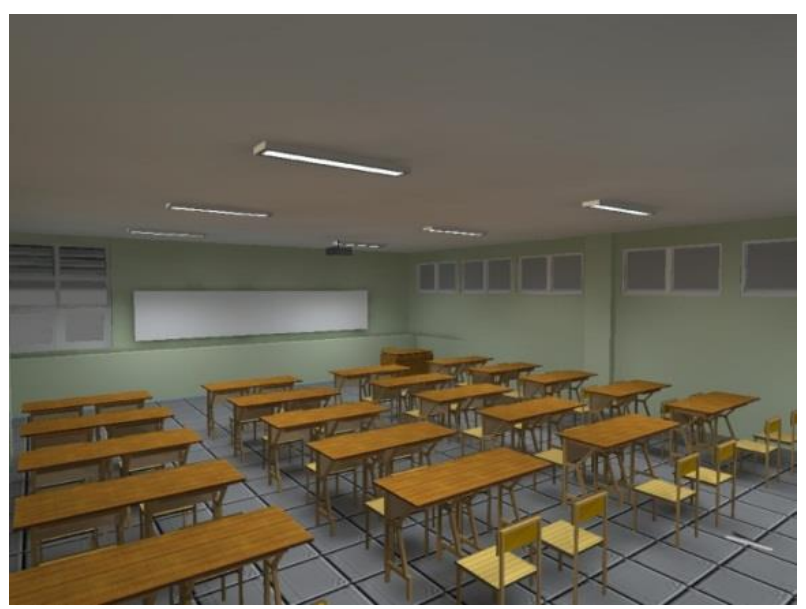

Gambar 3. Desain ruang kelas E11-210 dengan menggunakan Dialux

Pengukuran penerangan umum dan penerangan setempat dalam simulasi ini menggunakan 2 kondisi perubahan jenis armature yaitu armature TL LED (armature Slim LED) dan armature Bohlam LED (armature Bulb LED). Terdapat 5 variasi jenis armature TL LED yang digunakan dalam simu lasi seperti yang terlihat pada Tabel I dan Gambar 4 (a)(e). Simulasi variasi armature TL LED menggunakan 16 armature untuk simulasi setiap jenis armature TL LED dengan 16 lampu Philips TL-D 26 watt 3.900 lumen.

TABEL I. VARIASI ARMATURE TL LED PADA SIMULASI

\begin{tabular}{|c|l|c|c|}
\hline No. & \multicolumn{1}{|c|}{$\begin{array}{c}\text { Nama Armature TL } \\
\text { LED }\end{array}$} & $\begin{array}{c}\text { Daya } \\
\text { (Watt) }\end{array}$ & $\begin{array}{c}\text { Luminous Flux } \\
\text { (Lumen) }\end{array}$ \\
\hline 1 & $\begin{array}{l}\text { Powerbalance Gen2 } \\
\text { RC463B }\end{array}$ & 26 & 3.900 \\
\hline 2 & Powerbalance RC360B & 26 & 3.900 \\
\hline 3 & $\begin{array}{l}\text { Slimblend Rectangular } \\
\text { RC402B }\end{array}$ & 26 & 3.900 \\
\hline 4 & $\begin{array}{l}\text { Trueline Recessed } \\
\text { RC534B }\end{array}$ & 26 & 3.900 \\
\hline 5 & $\begin{array}{l}\text { Flexblend Recessed } \\
\text { RC342B }\end{array}$ & 26 & 3.900 \\
\hline
\end{tabular}

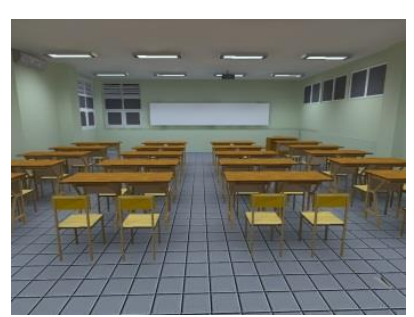

(a)

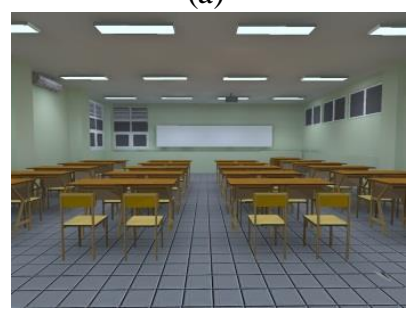

(c)

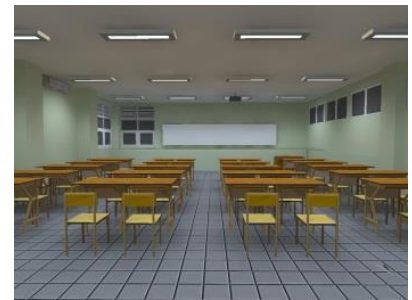

(b)

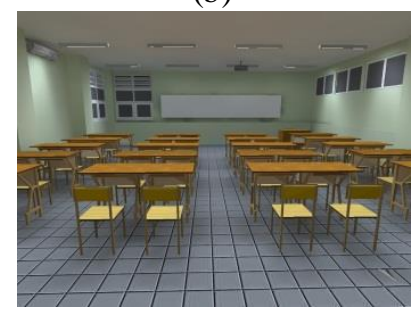

(d)

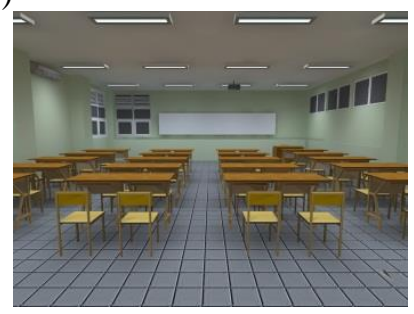

(e)

Gambar 4. Penerapan variasi armature TL LED (a) Powerbalance Gen2 RC463B, (b) Powerbalance RC360B, (c) Slimblend Rect angular RC402B, (d) Trueline Recessed RC534B, dan (e) Flexblend Recessed RC342B dalam ruang kelas E11-201

Simulasi dengan variasi Bohlam LED memiliki 5 jenis armature Bohlam LED yang digunakan seperti yang terlihat pada Tabel II dan Gambar 5 (a)-(e). Ju mlah armature Bohlam LED yang digunakan dalam simulasi untuk setiap jenis adalah 20 armature dengan 20 lampu ESS LedBulb 19 W 2.300 lumen. Dengan adanya variasi armature TL LED dan armature Bohlam LED akan didapatkan distribusi intensitas cahaya pada ruang kelas E11-210.

TABEL II. VARIASI ARMATURE BOHLAM LED PADA SIMULASI

\begin{tabular}{|c|l|c|c|}
\hline No. & \multicolumn{1}{|c|}{$\begin{array}{c}\text { Nama Armature } \\
\text { Bohlam LED }\end{array}$} & $\begin{array}{c}\text { Daya } \\
\text { (Watt) }\end{array}$ & $\begin{array}{c}\text { Luminous Flux } \\
\text { (Lumen) }\end{array}$ \\
\hline 1 & $\begin{array}{l}\text { Copenhagen LED Big } \\
\text { BDS441 }\end{array}$ & 19 & 2.300 \\
\hline 2 & $\begin{array}{l}\text { Luxspace Surface } \\
\text { Mounted DN571C }\end{array}$ & 19 & 2.300 \\
\hline 3 & $\begin{array}{l}\text { Luxspace Recessed } \\
\text { DN571B }\end{array}$ & 19 & 2.300 \\
\hline 4 & $\begin{array}{l}\text { Luxspace Recessed } \\
\text { DN570B }\end{array}$ & 19 & 2.300 \\
\hline 5 & $\begin{array}{l}\text { Luxspace Ace Accent } \\
\text { RS750B }\end{array}$ & 19 & 2.300 \\
\hline
\end{tabular}




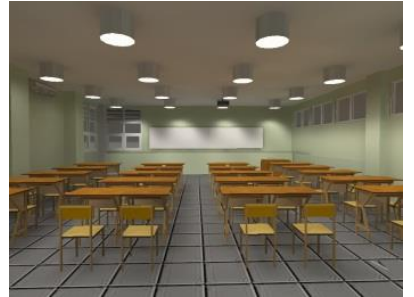

(a)

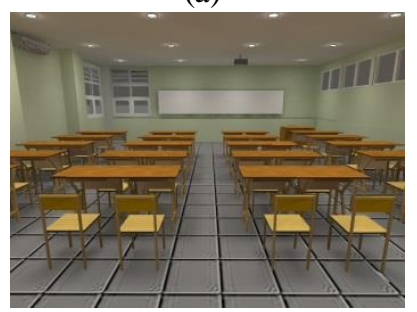

(c)

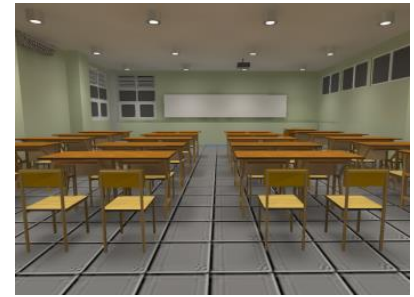

(b)

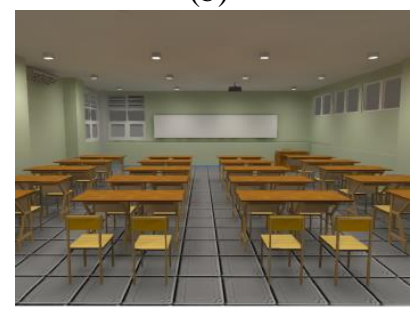

(d)

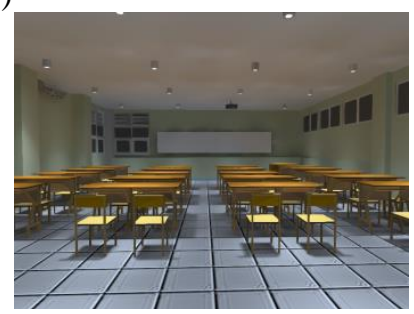

(e)

Gambar 5. Penerapan variasi armature Bohlam LED (a) Copenhagen LED Big BDS441, (b) Luxspace Surface Mounted DN571C, (c) Luxspace Recessed DN571B, (d) Luxspace Recessed DN570B, dan (e) Luxspace Ace Accent RS750B dalam ruang kelas E11-201

Terdapat 3 denah pemasangan lamp armature yang digunakan dalam simu lasi seperti yang terlihat pada Gambar 1 (b) dan Gambar 6 (a)-(b). Pada variasi armature TL LED menggunakan denah Gambar 6 (a) dengan pemasangan 16 armature TL LED (warna hijau). Sedangkan variasi armature Bohlam LED menggunakan denah Gambar 6 (b) dengan pemasangan 20 armature Bohlam LED (warna ungu).

Dengan adanya variasi jumlah armature yang digunakan dalam simulasi maka hasil simulasi diharapkan memiliki intensitas cahaya yang memenuhi standar SNI. Perhitungan biaya listrik dan efisiensi biaya listrik dalam simulasi ini berdasarkan jumlah lampu, biaya listrik per KWh dan daya lampu. Penelitian ini menggunakan biaya listrik per KWh bulan Oktober 2019 sesuai dengan Tarif Tenaga Listrik yang diberikan Perusahaan Listrik Negara (PLN) yaitu sebesar Rp $1.467,00$.

\section{HASIL DAN PEMBAHASAN}

Gambar 7 merupakan hasil simulasi distribusi intensitas cahaya pada ruang E11-210 sesuai dengan sistem pencahayaan yang diterapkan saat ini. Hasil simulasi yang terlihat pada Gambar 7 menunjukkan bahwa distribusi intensitas cahaya ruang kelas E11-210 antara 123 - 240 Lux sehingga masih belum memenuhi standar SNI. Hal ini didukung dengan hasil pengukuran secara observasi pada Tabel III menunjukkan bahwa ruang kelas E11-210 belum memenuhi standar SNI. Berdasarkan hasil observasi dan simulasi menggunakan Dialux dengan metode pengambilan data sesuai standar SNI 16-7062-2004 terlihat bahwa ruang kelas E11-210 belum memenuhi standar SNI.

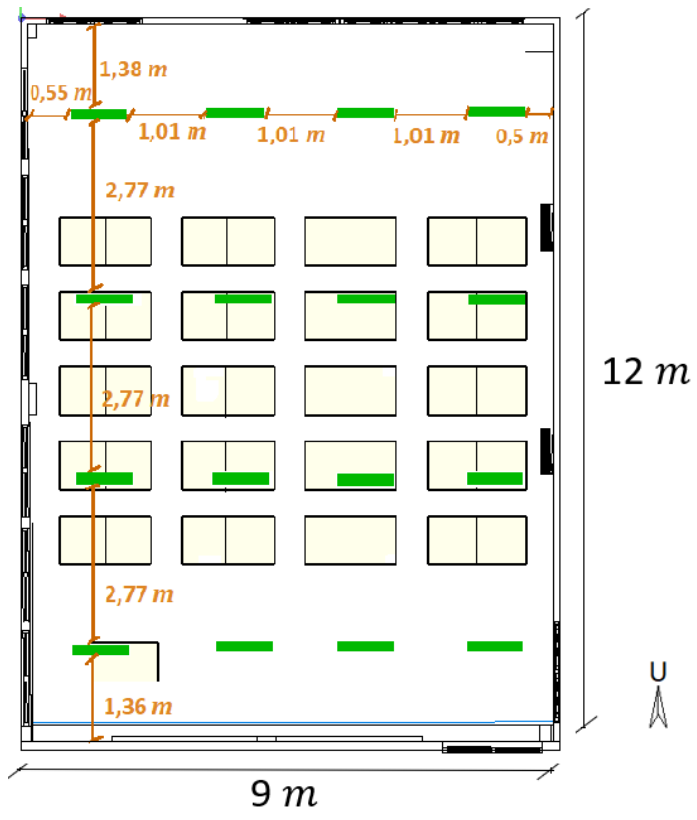

(a)

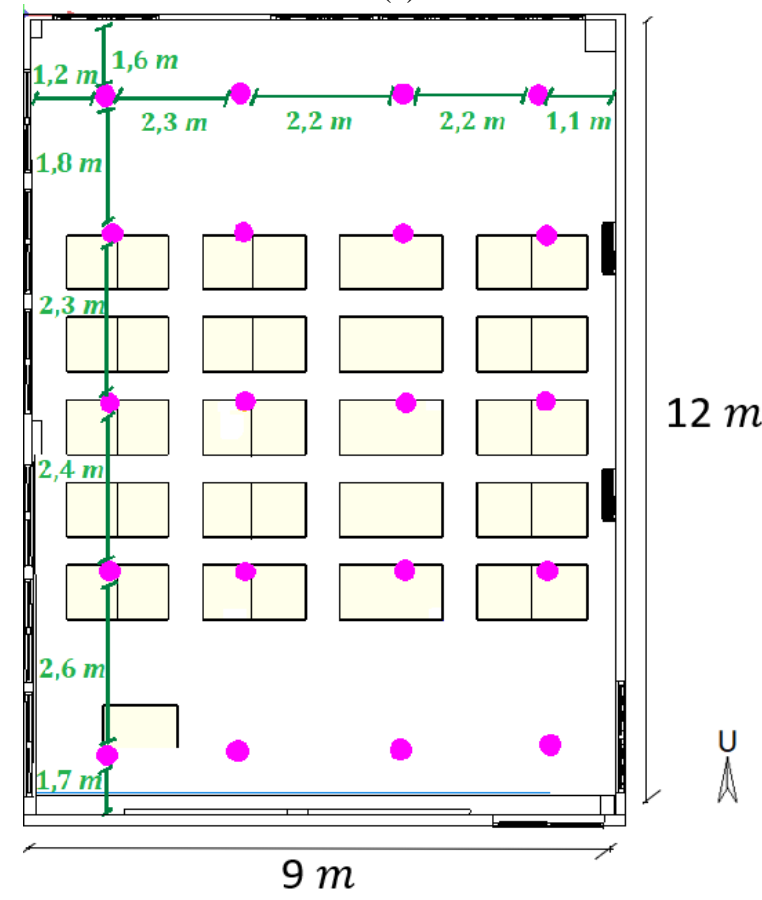

(b)

Gambar 6. Denah pemasangan (a) armature TL LED dan (b) armature Bohlam LED pada simulasi

TABEL III. HASIL OBSERVASI DAN SIMULASI DISTRIBUSI INTENSITAS CAHAYA PADA RUANG E1 1-210

\begin{tabular}{|c|l|c|c|}
\hline \multirow{2}{*}{ No. } & \multirow{2}{*}{$\begin{array}{c}\text { Jenis Pengukuran } \\
\text { Pencahayaan }\end{array}$} & \multicolumn{2}{|c|}{$\begin{array}{c}\text { Distribusi Intensitas Cahaya } \\
(\text { Lux })\end{array}$} \\
\cline { 3 - 4 } & & Observasi & Simulasi \\
\hline 1 & Pengukuran Umum & $185-211$ & $233-244$ \\
\hline 2 & Pengkuran Setempat & $110-221$ & $123-240$ \\
\hline
\end{tabular}




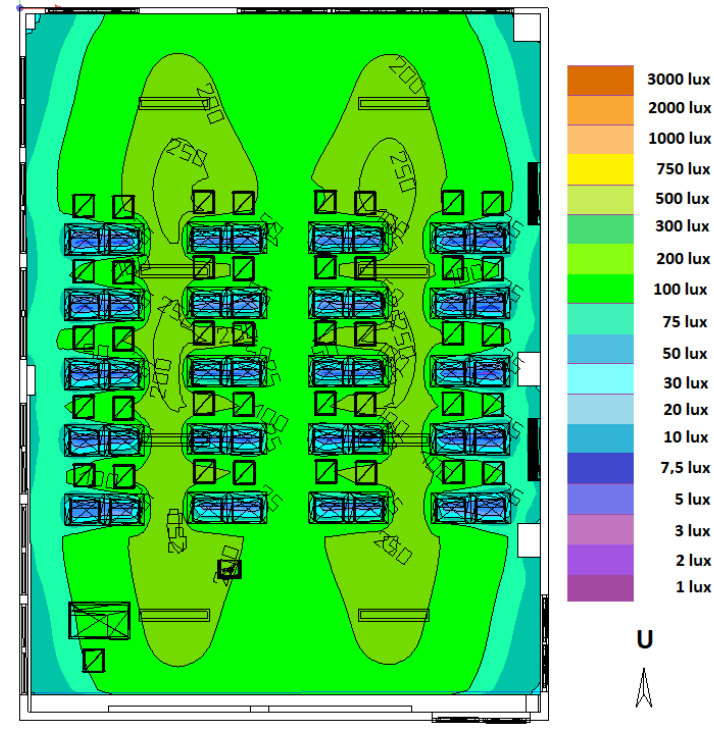

Gambar 7. Hasil simulasi distribusi intensitas cahaya ruang kelas E1 1-210 sesuai dengan sistem pencahayaan yang digunakan saat ini

Penelitian ini menggunakan variasi 5 armature TL LED dengan menggunakan daya dan luminous flux yang sama seperti pada Tabel I. Hal ini dilakukan agar dapat diketahui distribusi intensitas cahaya yang optimal dalam pengukuran umum maupun setempat yang sesuai dengan SNI. Terdapat 3 jenis armature TL LED yang terlihat pada Tabel IV yaitu nomor 1, 2 dan 3 dapat direkomendasikan sebagai pengganti armature yang digunakan saat ini. Hal ini dikarenakan armature nomor 1, 2, dan 3 memiliki intensitas cahaya ruang kelas E11-201 dapat memenuhi standar SNI. Penerapan prinsip interferensi cahaya yang saling menguatkan pada kisikisi armature nomor 1, 2, dan 3 dapat meningkatkan intensitas cahaya ruang kelas E11-201.

Armature Artolite RM300 M2 yang digunakan saat ini memiliki desain kisi-kisi armature serupa dengan armature nomor 1, 2 dan 3. A kan tetapi intensitas cahaya menggunakan armature Artolite RM300 M2 belum memenuhi standar SNI. Hal ini dikarenakan penggunaan armature Artolite RM300 M2 menggunakan lumen yang lebih kecil dibandingkan oleh armature nomor 1, 2, dan 3. Penggunaan lampu dan armature dengan lumen yang besar akan mempengaruhi penurunan kehandalan lampu. Sehingga armature no mor 1, 2, dan 3 akan memerlukan perawatan pada lampu dan lamp armature lebih banyak dibandingkan dengan armature Artolite RM300 M2.

Berdasarkan Tabel V terlihat bahwa hasil simulasi pengukuran umum dengan variasi armature Bohlam LED belum memenuhi SNI. Akan tetapi pada pengukuran setempat, armature nomor 5 (Luxspace Ace Accent RS750B) memiliki intensitas cahaya sesuai standar SNI. Hal ini dikarenakan distribusi arah pencahayaan armature nomor 5 tidak menyebar. Sehingga interferensi cahaya antar lampu akan saling menguatkan pada pengukuran setempat. Salah satu kenyamanan dalam proses belajar mengajar dapat diketahui berdasarkan intensitas cahaya pada masing-masing meja berdasarkan dari pengukuran setempat [5], [17]. Oleh karena itu armature Luxspace Ace Accent RS750B masih dapat direkomendasikan sebagai pengganti armature walaupun hanya hasil pengukuran setempat yang memenuhi SNI.

TABEL IV. HASIL SIMULASI DISTRIBUSI INTENSITAS CAHAYA PADA RUANG E11-210 DENGAN VARIASI TL ARMATURE

\begin{tabular}{|c|l|c|c|}
\hline \multirow{2}{*}{ No. } & \multirow{2}{*}{$\begin{array}{c}\text { Nama Armature TL } \\
\text { LED }\end{array}$} & \multicolumn{2}{|c|}{$\begin{array}{c}\text { Distribusi Intensitas Cahaya } \\
\text { (Lux) }\end{array}$} \\
\cline { 3 - 4 } & \multicolumn{1}{|c|}{$\begin{array}{c}\text { Pengukuran } \\
\text { Umum }\end{array}$} & $\begin{array}{c}\text { Pengukuran } \\
\text { Setempat }\end{array}$ \\
\hline 1 & $\begin{array}{l}\text { Powerbalance Gen2 } \\
\text { RC463B }\end{array}$ & $467-474$ & $382-506$ \\
\hline 2 & Powerbalance RC360B & $468-476$ & $383-505$ \\
\hline 3 & $\begin{array}{l}\text { Slimblend Rectangular } \\
\text { RC402B }\end{array}$ & $457-467$ & $377-475$ \\
\hline 4 & $\begin{array}{l}\text { Trueline Recessed } \\
\text { RC534B }\end{array}$ & $427-459$ & $326-540$ \\
\hline 5 & $\begin{array}{l}\text { Flexblend Recessed } \\
\text { RC342B }\end{array}$ & $300-305$ & $245-324$ \\
\hline
\end{tabular}

TABEL V. HASIL SIMULASI DISTRIBUSI INTENSITAS CAHAYA PADA RUANG E1 1-210 DENGAN VARIASI BOHLAM ARMATURE

\begin{tabular}{|c|l|c|c|}
\hline \multirow{2}{*}{ No. } & \multicolumn{1}{|c|}{$\begin{array}{c}\text { Nama Armature } \\
\text { Bohlam LED }\end{array}$} & \multicolumn{2}{|c|}{$\begin{array}{c}\text { Distribusi Intensitas Cahaya } \\
\text { (Lux) }\end{array}$} \\
\cline { 3 - 4 } & \multicolumn{1}{|c|}{$\begin{array}{c}\text { Pengukuran } \\
\text { Umum }\end{array}$} & $\begin{array}{c}\text { Pengukuran } \\
\text { Setempat }\end{array}$ \\
\hline 1 & $\begin{array}{l}\text { Copenhagen LED Big } \\
\text { BDS441 }\end{array}$ & $328-360$ & $203-359$ \\
\hline 2 & $\begin{array}{l}\text { Luxspace Surface } \\
\text { Mounted DN571C }\end{array}$ & $345-365$ & $297-370$ \\
\hline 3 & $\begin{array}{l}\text { Luxspace Recessed } \\
\text { DN571B }\end{array}$ & $339-356$ & $288-359$ \\
\hline 4 & $\begin{array}{l}\text { Luxspace Recessed } \\
\text { DN570B }\end{array}$ & $349-361$ & $290-360$ \\
\hline 5 & $\begin{array}{l}\text { Luxspace Ace Accent } \\
\text { RS750B }\end{array}$ & $323-495$ & $376-439$ \\
\hline
\end{tabular}

Perhitungan biaya listrik pencahayaan selama 1 jam dengan armature Artolite RM300 M2 dapat dilihat pada Tabel VI. Begitu juga pada Tabel VI dapat dilihat perhitungan biaya listrik pencahayaan selama 1 jam dengan jenis armature TL LED (Powerbalance Gen2 RC463B ) dan jenis armature Bohlam LED (Luxspace Ace Accent RS750B). Jenis armature nomor 2 dan 3 pada Tabel VI digunakan dalam perhitungan biaya listrik pencahayaan karena hasil simulasi menunjukkan bahwa armature jenis tersebut memenuhi SNI.

TABEL VI. PERHITUNGAN BIAYA LISTRIK PENCAHAYAAN RUANG KELAS E1 1-210 DENGAN ARMATURE YANG SAAT INI DIGUNAKAN, ARMATURE TL LED, DAN ARMATURE BOHLAM LED

\begin{tabular}{|c|l|c|c|c|c|}
\hline No. & \multicolumn{1}{|c|}{$\begin{array}{c}\text { Jenis } \\
\text { Armature }\end{array}$} & $\begin{array}{c}\text { Daya } \\
\text { Lampu } \\
\text { (Watt) }\end{array}$ & $\begin{array}{c}\text { Jumlah } \\
\text { Lampu } \\
\text { Listrik } \\
\text { per } \\
\text { Kwh } \\
(\mathbf{R p})\end{array}$ & $\begin{array}{c}\text { Total } \\
\text { Biaya } \\
\text { Listrik } \\
\text { (Rp) }\end{array}$ \\
\hline 1 & $\begin{array}{l}\text { Artolite } \\
\text { RM300 M2 }\end{array}$ & 36 & 16 & 1.467 & 845 \\
\hline 2 & $\begin{array}{l}\text { Powerbalance } \\
\text { Gen2 RC463B }\end{array}$ & 26 & 16 & 1.467 & 610 \\
\hline 3 & $\begin{array}{l}\text { Luxspace Ace } \\
\text { Accent } \\
\text { RS750B }\end{array}$ & 19 & 20 & 1.467 & 558 \\
\hline
\end{tabular}


Berdasarkan Tabel VI dapat dihitung nilai efisiensi dari penggantian armature dengan menggunakan armature TL LED sebesar $27,81 \%$ sedangkan penggantian armature dengan menggunakan armature Bohlam LED sebesar 33,96 \%. Biaya perawatan maupun parameter penurunan kehandalan masih belum diperhitungkan dalam efisiensi biaya listrik tersebut. Hasil simulasi dalam penelitian ini sesuai dengan referensi [4] yang medapatkan efisiensi 34\% dengan penggantian armature Flourescent Tubular Lamps (FTL) menjadi TL LED dan penggantian lampu TL dengan lampu LED. Pada penelitian ini menunjukkan bahwa dengan adanya pemilihan lamp armature yang sesuai dengan ruang kelas akan menghemat biaya biaya listrik yang signifikan walaupun jenis lampu yang digunakan sama.

\section{PENUTUP}

Berdasarkan pengukuran secara observasi maupun simulasi, intensitas cahaya pada ruang kelas E11-201 belum memenuhi standar SNI. Penggantian lamp armature E11-201 yang digunakan saat ini dengan armature TL LED maupun armature Bohlam LED dapat mengakibatkan intensitas cahaya ruang kelas E11-201 memenuhi standar SNI. Nilai efisiensi biaya listrik pencahayaan dengan penggantian armature TL LED sebesar 27,81\% sedangkan dengan penggantian armature Bohlam LED sebesar 33,96\%. Dengan adanya pemilihan jenis lamp armature yang sesuai ruang kelas dan penggunaan lampu yang sama dalam penelitian ini dapat menghemat biaya listrik yang signifikan. Penelitian selanjutnya dapat memperhitungkan biaya perawatan maupun parameter kehandalan lampu dan armature agar didapatkan prediksi efisiensi biaya listrik pencahayaan lebih tepat.

\section{REFERENSI}

[1] Kementrian Energi dan Sumber Daya Mineral, Statistik Ketenagalistrikan 2017, Jakarta, 2017.

[2] Kementrian Energi dan Sumber Daya Mineral, Keputusan Menteri ESDM tentang Rencana Umum Ketenagalistrikan Nasional 2008 s.d. 2027, 2008.

[3] E. Ghisi, T. C. Stahnke Manorov, L. Niehuns Ant unes, and L. Padilha Thives, "Electricity Savings Due to the Replacement of Fluorescent Lamps with LEDs in Classrooms," Eur. J. Sustain. Dev., vol. 8, no. 4, pp. 64-74, 2019.

[4] T. Tejwani, R. Chikhalikar, and Siddhartha, "Energy Conservation in an Educational Institution - Through Lighting Optimization Techniques," in 2019 Innov. Power Adv. Comput. Technol, pp. 1-7, 2019.

[5] L. T. Doulos, A. Kontadakis, E. N. Madias, M. Sinou, and A.
Tsangrassoulis, "Minimizing energy consumption for artificial lighting in a typical classroom of a Hellenic public school aiming for near Zero Energy Building using LED DC luminaires and day light harvesting systems," Energy Build., vol. 194, pp. 201-217, 2019.

[6] M. Fontoynont, "LED lighting, ultra-low-power light ing schemes for new lighting applications," Comptes Rendus Phys., vol. 19, no. 3, pp. $159-168,2018$.

[7] D. . Erhat, M. Haag, A. Schmitt, D. Guerlich, M. Bonomolo, and U. Eickr, "Retrofitting Existing University Campus Buildings to Improve Sustainability and Energy performance" in Proc PLEA 2016, pp. 1-8, 2016.

[8] M. Bonomolo, C. Baglivoa, G. Bianco, P. M. Congedo, and M. Beccali, "Cost optimal analysis of lighting retrofit scenarios in educational buildings in Italy," Energy Procedia, vol. 126, pp. 171-178, 2017.

[9] M. F. Lee and N. Q. Zulkafli, "A Case Study on Energy Saving Through Lighting System for Building: An Internal Energy Review," in 2016 IEEE 6th Int. Conf. Power Energy, Conf. Proceeding, pp. 575$579,2016$.

[10] B. Stankovic, A. Kostic, and M. J. Popovic, "Energy for Sustainable Development Analysis and comparison of lighting design criteria in green building certi fi cation systems - Guidelines for application in Serbian building practice," Energy Sustain. Dev., vol. 19, pp. 56-65, 2014.

[11] M. Petkovic, D. Bajovic, D. Vukobratovic, G. McCutcheon, L. Stankovic, and V. Stankovic, "Effect of external daylight in smart dimmable LED lighting systems" in Proc WOCC 2019 - Proceedings, 2019, pp. 1-5.

[12] L. L. Fernandes, E. S. Lee, D. L. Dibartolomeo, and A. Mcneil, "Monitored light ing energy savings from dimmable lighting controls in The New York Times Headquarters Building," Energy Build., vol. 68, no. Part A, pp. 498-514, 2014.

[13] M. S. S. Purnama and D. Sutanto, "Dynamic facade module prototype development for solar radiation prevention in high rise building," in IOP Conf. Ser. Earth Environ. Sci., 2018.

[14] A. A. Freewan and L. W. Shqra, "Analysis of energy and daylight performance of adjustable shading devices in region with hot summer and cold winter," Adv. Energy Res., vol. 5, no.4, pp. 289-304, 2017.

[15] A. Cilasun, "Using Daylight Systems To Reduce Energy Consumption Due To Lighting: A Case Study Of Yaşar University Cafeteria," Assoc. Build. Phys., p. 10, 2016.

[16] A. Tsangrassoulis, A. Kontadakis, and L. Doulos, "Assessing Lighting Energy Saving Potential from Daylight Harvesting in Office Buildings Based on Code Compliance \& Simulation Techniques: A Comparison," Procedia Environ. Sci., vol. 38, pp. 420-427, 2017.

[17] N. Giraldo, M. Longhinotti, F. O. R. Pereira, and A. Kuhnen, "Luminous and visual preferences of young children in their classrooms : Curtain use, artificial light ing and window views," Build. Environ., vol. 152, pp. 59-73, 2015.

[18] N. Castilla, C. Llinares, and F. Bisegna, "Emotional evaluation of lighting in university classrooms : A preliminary study," Front. Archit. Res., 2018.

[19] Badan Standarisasi Nasional, SNI 16-0762-2004 tentang Pengukuran intensitas penerangan di tempat kerja. 2004.

[20] Badan Standarisasi Nasional, SNI 6197: 2011 tentang Konservasi energi pada sistem pencahayaan. 2011. 